\title{
SKRIFGEBRUIK IN DIE BEOORDELING VAN UITSPRAKE OOR DIE DOODSTRAF
}

F Klopper

\begin{abstract}
USE OF SCRIPTURE IN THE EVALUATION OF STATEMENTS REGARDING CAPITAL PUNISHMENT.

The thesis of this article holds that in modern society it is not possible to rest findings for or against capital punishment solely upon Scriptural testimony. A relational view of Scripture is adopted which takes into account that the text is historically determined; was meant to fulfil a particular function in an ancient society and was therefore written from a perspectivist view on reality. It denies that Scriptural norms are directly applicable to all times and in every situation.
\end{abstract}

\section{Aktualiteit}

Die probleem rakende die toepassing van die doodstraf aldan nie, is 'n aktuele probleem wêreldwyd. In ons land het daar eweneens tussen teoloë en juriste meningsverskille oor die onderwerp bestaan wat steeds uitdrukking vind in die populêre pers. Die voor-die-hand-liggende rede vir die kontensieuse aard van die onderwerp is dat die doodstraf per definisie ' $n$ strafmaatreël is wat die beredeneerde beëindiging van 'n menselewe tot gevolg het - optrede wat om ernstige besinning vra.

Hierdie bespreking het nie ten doel om op grond van Skrifgetuienis (en in besonder Ou-Testamentiese getuienis omdat die Nuwe Testament weens die aard van sy kultuur-historiese milieu en geskrifte nie eksplisiete verwysings na die doodstraf bevat nie) 'n uitspraak te lewer oor die handhawing of afskaffing van die doodstraf nie. So 'n uitspraak is immers nie moontlik sonder om hedendaagse regsbeginsels en etiese eise in aanmerking te neem en "in gesprek te laat tree" met Bybelse regsuitsprake en norme nie, en dit val gewoon buite die veld van hierdie bespreking.

\section{Probleemstelling}

Die probleem wat hier aandag kry, is 'n hermeneutiese een en word verwoord in die amptelike standpunt van die Nederduitse Gereformeerde Kerk oor doodstraf (soos vervat in die Algemene Sinode se goedkeuring van die standpunt van die Breë Moderatuur), naamlik dat die afskaffing van die doodstraf "nie in ooreenstemming is met ons interpretasie (my beklemtoning) van die Skrif nie". ") Die kern van die probleem wat uit die aanhaling na vore tree, is dat daar, tereg, meer as een Skrifbeskouing veronderstel word. Omdat elke Skrifbeskouing as menslike perspektief histories-sosiaal deur omstandighede en tradisies 